\title{
Corporate Governance Practices and Firms' Financial Performance of Selected Manufacturing Companies in Lagos State, Nigeria
}

\author{
Yimka Samson Akanfe Alalade ${ }^{1,}$,, Babatunde Babasola Onadeko², Okezie Fine-Country Okezie ${ }^{3}$ \\ ${ }^{1}$ Department of Banking and Finance, Babcock University, Ilishan-Remo, Nigeria \\ ${ }^{2}$ First City Monument Bank, Sagamu, Nigeria \\ ${ }^{3}$ Federal Inland Revenue Service, Lagos, Nigeria
}

Email address:

alalades@babcock.edu.ng (Y. S. A. Alalade)

*Corresponding author

\section{To cite this article:}

Yimka Samson Akanfe Alalade, Babatunde Babasola Onadeko, Okezie Fine-Country Okezie. Corporate Governance Practices and Firms' Financial Performance of Selected Manufacturing Companies in Lagos State, Nigeria. International Journal of Finance and Banking Research. Vol. 5, No. 6, 2019, pp. 154-165. doi: 10.11648/j.ijfbr.20190506.14

Received: September 8, 2019; Accepted: October 4, 2019; Published: November 7, 2019

\begin{abstract}
Nigerian companies adopted the code of best practice on corporate governance in 2003, through which private and public firms are mandated to operate accordingly. Many companies have complied while some have failed to so. This study examined corporate governance practices eight years after (2010), given the instability in the political and economic environment under which they operated. The study also examined the relationship between corporate governance practices and firms' financial performance in the selected manufacturing companies in Lagos State, Nigeria. The study employed a comparative analysis to gauge the changes to corporate governance practice between the years 2003 to 2010 by manufacturing companies. The companies were selected based on availability of data from the stock exchange in terms of activities of trading and existence of reports on corporate governance in the companies' annual reports. The study used both descriptive statistics and econometrics method of analysis, using E-views 7 statistical software. The Panel data of the ten companies for the 8 years was used, employing ordinary least square (OLS) method of analysis. Consequently, the results of the descriptive statistics show that majority of the companies implemented the code of conduct that emphasizes appropriate composition of the board of directors and forecast of operations. Further analysis shows that there was positive relationship between the return of equity and legal compliance, though the relationship is weak given the value of $\mathrm{R}$ as 0.197 . Also, there were weak relationships between return on equity $(\mathrm{ROE})$ and board compliance as $\mathrm{R}=-0.4430$ and proactive indicators $\mathrm{R}$ as -0.2345 . These imply that while the companies obey the regulations in term of board composition, legal compliance and production projections, which are the major concerns of this study. Meanwhile, some other variables impacted more on ROE.
\end{abstract}

Keywords: Corporate Governance, Financial Performance, Return on Equity, Manufacturing Firms, Board Composition

\section{Introduction}

Corporate governance practices are seen to have great impact to maximization of stakeholder wealth and to the growth prospects of an economy. They are practices considered as paramount to management of constraint, such as the issue of reducing risk for investors, attracting investment capital, and improving the performance of companies. However, the way in which corporate governance is organized differs from company to company and from country to another, depending on their economic, political and social situations.

Corporate Governance has been perceived differently by different people. Magdi and Nadereh [24] and Kajola [23] concurred that corporate governance is making sure the business is well managed and shareholders interest is protected at all times. Organization for Economic Cooperation and Development (OECD) [34] claimed corporate governance is broad in practice. It defines corporate governance as the system by which business 
corporations are directed and controlled. It further states that the corporate governance structure specifies the distribution of rights and responsibilities among different participants in the corporation such as, the board, managers, shareholders and other stakeholders; and thus spells out the rules and procedures for making decisions on corporate affairs. It also provides the structure through which the company's objectives are set and the means of attaining those objectives and monitoring performance [3].

Financial scandals around the world and the recent collapse of major corporate institutions in the Nigeria such as Oceanic Bank, Intercontinental Bank and Cadbury have shaken the faith of investors in the capital markets and the efficacy of existing corporate governance practices in promoting transparency and accountability. This has brought to the fore the need for the practice of good corporate governance. Corporate performance is an important concept that relates to the way and manner in which financial resources available to an organization are judiciously used to achieve the overall corporate objective of an organization, which in-turn, keeps the organization in business and creates a greater prospect for future opportunities.

There have been debates regarding the issue of corporate governance in Nigeria, involving both local and international stakeholders in the business realm. It has been addressed as one of the major factors that have led to a reduction in capital flows and subsequent slow down the rate of economic growth in the country. However, since the adoption of corporate governance code of conducts, there has been a steady trend towards implementing good governance structures both in public and private sectors.

The introduction of corporate governance practices in Nigeria is aimed at providing a mechanism to improve the confidence and trust of investor in the management and promote economic development of the country. However, efficiency of the corporate governance structures and practices on corporations operating in the highly volatile environment of Nigeria has not been empirically investigated [32]. In order to understand the governance practices that contribute to enhance the value of listed companies in Nigeria, this study explored the efficacy of corporate governance practices, which affect firm performance resulting in accountability to shareholder and other stakeholders through appropriate corporate reporting practices, which enhances the value of the firms of listed companies in Nigeria. The essence of this study is to examine the impact of the corporate governance mechanism on firm performance and provide additional insights into the relationship between four corporate governance mechanisms (board size, board composition, chief executive status and audit committee) and firm performance in Nigeria. The focus is on four dimensions of corporate governance.

\section{Statement of Problem}

The effect of corporate governance on the financial performance of firms was an important issue since the last financial distresses over the world. Thus, the main idea of this study is to examine whether or not the independent variable factors (Corporate Governance) taken into consideration in this study can influence the performance indicators of the firms' financial performance. Therefore, the major intention of this study is to examine the relationship between corporate governance practices and firms' financial performance in the manufacturing sector in Nigeria. In order words, the issue of concern was how have the practices of corporate governance influences financial performance of selected manufacturing firms in Lagos State, Nigeria.

The study was set to determine how corporate governance practices affect firms' financial performance in the manufacturing sectors of the economy and to ascertain to what extent corporate governance practices explain the dynamism of the performance of manufacturing firms. The study hypothesized that: legal compliance as a component corporate governance practices has no significant effect on manufacturing firms' performance. (2) Board composition as a corporate governance practice has no significant effect on performance of manufacturing firms. (3) Proactive board does not guarantee enhanced performance in the manufacturing sector. (4) Totality of corporate governance practices does not have significant effect on performance of the manufacturing firms. (5) Corporate governance practices do not substantially explain variations in firms' performance in the manufacturing sector.

\section{Review of Related Literature}

Corporate Governance theories range from the agency theory and expanded into stewardship theory, stakeholder theory, resource dependency theory, transaction cost theory, political theory and ethics related theories such as business ethics theory, virtue ethics theory, feminist's ethics theory, discourse theory to postmodernism ethics theory. The following are the review of few of the related theories to the study.

1) Agency Theory: The Agency theory having its roots in economic theory was exposited by Alchian and Demsetz in 1972 and further developed by Jensen and Meckling in 1976. The Agency theory is defined as the relationship between the principals, such as shareholders and agents such as the company executives and managers. In this theory, shareholders who are the owners or principals of the company, hire the agents to perform the work. Principals delegate the running of business to the directors or managers, who are the shareholder's agents [10]. Meanwhile, Daily, Dalton and Canella [14] argued that two factors could influence the prominence of agency theory. First, the theory is conceptual and simple theory that reduces the corporation to two participants of managers and shareholders. Second, agency theory suggests that employees or managers in organizations can be self-interested. The agency theory states that shareholders expect the agents to act and make decisions in the principal's interest. On the contrary, the agent may not necessarily make decisions in the best interests of the principals [35]. Such a problem was first highlighted by Adam Smith in the 18th century and subsequently explored 
by Ross in 1973, and the first detailed description of agency theory was presented by Jensen and Meckling in 1976. Indeed, the notion of problems arising from the separation of ownership and control in agency theory has been confirmed by Davis, Schoolman and Donaldson in 1997. With agency theory, the agent may be succumbed to self-interest, opportunistic behavior and falling short of congruence between the aspirations of the principal and the agent's pursuits, even with the understanding of risk defers in its approach. Although with such setbacks, agency theory was introduced basically as a separation of ownership and control [6]. It has been argued that instead of providing fluctuating incentive payments, the agents would only focus on projects that have a high return and have a fixed wage without any incentive component. Although this will provide a fair assessment, but it does not eradicate or even minimize corporate misconduct [31]. Here, the positivist approach is used where the agents are controlled by principal-made rules, with the aim of maximizing shareholders value. Hence, a more individualistic view is applied in this theory [10]. Indeed, agency theory can be employed to explore the relationship between the ownership and management structure. However, where there is a separation, the agency model can be applied to align the goals of the management with that of the owners.

2) Stewardship Theory: The Stewardship theory presents a contrasting view to agency theory. This theory asserts that, there will not be any major agency costs, since managers are naturally trustworthy [1]. According to the perspective of the 'stewardship theorists, managers are inherently trustworthy and faithful stewards of the corporate resources entrusted to them. Managers are good stewards of the organization and it is in their own interest to work to maximize corporate profits and shareholder returns. Therefore, proponents of stewardship theory argue that firm performance is linked to a majority of inside directors and combined leadership structure [1]. Stewardship theory sees a strong relationship between managers striving to successfully achieve the objectives of the firm, and the resulting satisfaction accorded to investors or owners, as well as other participants in the enterprise [10]. A virtuous circle is evident in stewardship theory, where stewards protect and maximize shareholder wealth through firm performance, which results in maximizing the stewards' utility. Therefore, by improved firm performance, the organization satisfies most groups that have an interest in the organization. Thus, stewardship theory supports the need to combine the role of the chairman and CEO, and favor boards consisting of specialist executive directors rather than majority non-executive directors.

3) Stakeholder Theory: The Stakeholder theory was embedded in the management discipline in 1970 and was gradually developed by Freeman in 1984, which incorporated corporate accountability to a broad range of stakeholders. Wheeler, Colbert and Freeman [39] argued that the stakeholder theory is derived from a combination of the sociological and organizational disciplines. Indeed, stakeholder theory is less of a formal unified theory and more of a broad research tradition, incorporating philosophy, ethics, political theory, economics, law and organizational science. Donaldson and Preston [15] opined that this theory focuses on managerial decision making and the interests of all stakeholders have intrinsic value, and no sets of interests are assumed to dominate the others. Unlike agency theory in which the managers are working and serving the stakeholders, stakeholder theorists suggest that managers in organizations have a network of relationships to serve the like of the suppliers, employees and business partners. It argued that this group of network is important other than owner-manager-employee relationship as in agency theory [39]. On the other end, Sundaram and Inkpen [37] contended that the stakeholder theory attempts to address the group of stakeholders that deserve and require the attention of the management. Since the purpose of all stakeholders in business is to obtain benefits, it has been argued that the firm is a system, where there are stakeholders and the purpose of the organization is to create wealth for its stakeholders. Also, since the network of relationships with many groups can affect decision-making processes, as the stakeholder theory is concerned with the nature of these relationships in terms of both processes and outcomes for the firm and its stakeholders [5].

4) Resource Dependency Theory: Whilst the stakeholder theory focuses on relationships with many groups for individual benefits, the resource dependency theory concentrates on the role of board directors in providing access to resources needed by the firm. Hillman, Canella and Paetzold [20] contended that resource dependency theory focuses on the role that directors play in providing or securing essential resources for an organization through their linkages to the external environment [4]. Meanwhile, Wanyama and Olweny [38] agreed that resource dependency theorists provide focus on the appointment of representatives of independent organizations as a means for gaining access in resources critical to firm success. For example, outside directors who are partners to a law firm provide legal advice, either in board meetings or in private communication with the firm executives that may otherwise be more costly for the firm to secure. It has been argued that the provision of resources enhances organizational functioning, firm's performance and its survival [14]. According to Hillman, Canella and Paetzold [20], directors bring resources to the firm, such as information, skills, and access to key constituents such as suppliers, buyers, public policy makers, social groups as well as legitimacy. Directors can be classified into four categories of insiders, business experts, support specialists and community influential. First, the insiders are current and former executives of the firm and they provide expertise in specific areas such as finance and law on the firm itself as well as general strategy and direction. Second, the business experts are current, former senior executives and directors of other large for-profit firms and they provide expertise on business strategy, decisionmaking and problem solving. Third, the support specialists are the lawyers; bankers, insurance company representatives 
and public relations experts and these specialists provide support in their individual specialized field. Finally, the community's influential are the political leaders, university faculty, members of clergy, and leaders of social or community organizations.

5) Business Ethics Theory: Business ethics is a study of business activities, decisions and situations where the rights and wrongs are addressed. The main reasons for this are that the power and influence of business in any given society is stronger than ever before. Businesses have become major provider to the society, in terms of jobs, products and services. Business collapse has a greater impact on society than ever before and the demands placed by the firm's stakeholders are more complex and challenging. Only a handful of business giants have had any formal education on business ethics, but there seems to be more compromises these days. Business ethics provides us ability to identify benefits and problems associated with ethical issues within the firm and so, business ethics is essential as it gives us a broader knowledge into present and traditional view of ethics [12]. In understanding the 'right and wrongs' in business ethics, Crane \& Matten [12] injected morality that is concerned with the norms, values and beliefs fixed in the social process which help define rights and wrongs for an individual or social community. Ethics is defined as the study of morality and the application of reason which sheds light on rules and principle, which is called ethical theories that ascertains the right and wrong for a situation.

The purpose for emerging economies to employee external corporate governance is the need to institute confidence of investors in order to attract and retain foreign and local investment to expand the trade [19]. The International Monetary Funds, World Bank as well as organizations such as the OECD indirectly mandates developing countries to improve their external corporate governance mechanisms and regulatory infrastructure [3]. The effects of these changes can be seen in the actions of investors who are increasingly becoming confident in investing in some markets, which were considered risky earlier. However, the corporate sectors in emerging, countries do seem to lag behind the benchmark for sound corporate governance [28].

The economic crisis that hit the South East Asian stock markets in 1997-1998 was partly attributed to weak corporate governance in the region, which prompted governments to consider ways of improving governance structures in their countries [28]. This resulted in governance reforms in the emerging markets for restoring investor confidence by providing a secure institutional platform to build an investment market [29]. Therefore, codes of corporate governance were established by most of these countries to promote a continuous flow of funds and to boost the confidence of investor in their capital markets [18]. Even though emerging markets are aware of the concept of corporate governance, implementation of corporate governance practices has not been effective [28]. The codes, which were derived from recommendations in developed countries, may not be applicable to developing countries, due to their national character, economic prosperity and social priorities. Therefore, what is effective in one country may not be so in another. Likewise, every corporation has its unique characteristics due to their history, culture and business goals. Hence, all these factors needed to be taken into account in their efforts to reform corporate governance [18].

As the business environment of the developed countries is different from that of emerging countries, the governance structures designed to enhance performance should take into account the unique business environment that exists in the country without blindly adopting the practices from other countries. For example, Haniffa and Hudaib [18] concluded from a study on Malaysian listed companies, that the applicability of recommendations derived by the Cadbury Report and Hampel Report in the UK may be disputable due to high ownership concentration, close control by owners and substantial shareholders, cross-holdings of share ownership or pyramiding, and the close relationship between the firms, banks and the government.

Corporate governance is affected by the ownership structure of the firm in the emerging markets. The findings from the above Malaysian study are not unique. One or several members of a family often tightly hold the shares of Asian Corporations and voting rights held by the family is usually higher than their cash flow rights. In addition to family ownership, a significant number of listed companies are controlled by the state, in countries such as Singapore and China. Moreover, financial institutions are less common in developing countries in Asia [9].

In the emerging economies, the quality of public governance determines corporate governance practices. For example, Asian economies are plagued by corruption and rent seeking, which has been reported as an important source of corporate profits. Furthermore, there was widespread collusion between politicians and entrepreneurs to extract or protect monopoly profits. It is unlikely that high quality corporate governance practices will arise rapidly in the region [9]. There are a number of studies in the emerging markets, which have reported that political connections were valued by investors [16].

A study on the linkages between the OECD and emerging South East Asian stock markets reveals that fluctuations in the stock markets in emerging markets are caused by the fluctuations in their own regional markets, rather than the fluctuations in the advanced markets [26]. However, Cooray and Wickremasinghe [11] state that stock markets cannot use the share returns of a particular market in the region to predict the returns of others in the South Asian Region. Emerging markets are currently going through a transition stage where a younger and more educated generation is taking over the family businesses. They are not only participant in implementing change dealing with globalization, culture and family traditions, but are also providing a supportive environment for the successful implementation of corporate governance, between the firms, banks and the government [17].

Over the years, Nigeria as a nation has suffered a lot of 
decadence in various aspects of her national life, especially during the prolonged period of military dictatorship under various heads. The political and business climate had become so bad that by 1999 when the nation returned to democratic rule, the administration of President Obasanjo inherited a pariah state noted to be one of the most corrupt nations of the world. Most public corporations, such as NITEL, NNSL, NEPA, and NRC were either dead or simply drainpipes of public resources, while the few factories that were merely available were working below capacity. The banks with their super profits were collapsing in their numbers, leaving a trail of woes for investors, shareholders, suppliers, depositors, employees and other stakeholders. It was as a result of the disorganized state of the nation then that led the government to make a bold step in initiating the corporate governance evolution.

In view of the importance attached to the institution of effective corporate governance, Federal Government of Nigeria, through her various agencies have come up with various institutional arrangements to protect the investors of their hard earned investment from unscrupulous management and directors of listed firms in Nigeria. These institutional arrangements, provided in the "code of corporate governance best practices" issued in November 2003.

Corporate governance has attracted a great deal of public attention because of its importance to the economic health of companies and its effect on society in general [36]. As it has significant implications for the growth prospects of an economy, numerous recent corporate failures around the world and in Nigeria especially, have alerted regulators to the importance of sound corporate governance for the efficient operations of capital markets. This is because implementation of proper corporate governance practices reduces the risk for investors, attracts investment capital, and improves corporate performance [36].

Corporate governance is an important component for firm performance as well as for the overall growth of the economy of the country [8]. They further explain that the one point increase in overall corporate governance index would result in around a half percent increase in net revenues and worst to best change in overall corporate governance index predicts about $40 \%$ increase in company's net revenue. This assertion provides us some thought that there is a positive relationship between corporate governance and firm performance. They then recommend that shareholders should monitor and pressurize the managers through directors, for optimal usage of the capital to raise the value of the shareholders [7].

Magdi and Nadereh [24] stress that corporate governance is about ensuring that the business is running well and investors receive a fair return. Core corporate governance institutions respond to two distinct problems; namely, one of vertical governance which is between distant shareholders and managers; and another of horizontal governance which exist between a close, controlling shareholder and distant shareholders. The results drawn by different researchers about the impact of corporate governance on firm performance are positive and direct, but some researchers also had drawn negative and indirect results.

According to Cremers and Nair [13], they opined that corporate governance either it is external or internal, plays an important role in enhancing the performance and value of the firm. Mathiesen [27] concurred that corporate governance, is a field in economics that examines how to secure and motivate efficient management by the use of incentive mechanism. Maher and Anderson [25] opined that there are some complexities and hurdles with system of corporate governance, as they had mentioned that in different countries corporate governance may be distinguished due to difference in ownership structure and controlling authorities of the firms. They further proposed that this system could be divided into two (2) different categories: insiders system and outsiders system. In outsiders system, there is a conflict between strong managers and widely dispersed shareholders. On the other hand, in insiders system the conflict is between strong and weak shareholders. The finding of their study was that corporate governance has strong impact over the capital market and also on the allocation of the resources.

Mulili and Wong [30] stressed that corporate governance is as extensively important to the value of the firm as the policies are important for the firm to grow. In the same article, it is also found out that the firms that are shareholder and manager friendly have attained negative abnormal returns. Therefore, the researcher recommended that the firm must practice corporate governance in order to get the better returns in future. Nworji, Olagunju and Adeyanju [32] stated that corporate governance plays an important role in enhancing the market confidence of the firm and also leads the firm towards prosperity and stability.

Olusanya and Oluwasanya [33] argued that the firms that practice good corporate governance are more profitable and prosperous. Not only do they earn more profit but also these firms pay more to their shareholders, thereby increasing stakeholders' wealth. They argued further that good governance is concerned with the executives and the directors. Their findings depict that companies that followed the charter and laws, are more associated with the bad performance. Their conclusion suggests that there is no significant and positive relationship between firm performances, considering the mentioned provisions of the corporate governance.

For comparison between developed and developing nations, Ironkwe and Adee, [22] had come to know that corporate governance play equally and balanced role in enhancing the performance of the firms in both developed and developing nations. But there might be the little bit difference between the relationship of corporate governance and value of the firms in developed and developing financial markets. This difference may be due to difference in corporate governance structures because of different social economic law and order situations in that particular country. So first of all, we have to find out these differences that affect the performance and value of the firm. The study shows that corporate governance is favorable for effective use of assets to improve the value of the firm. Also, there was evidence 
that large board size, could lead the firm towards developing financial markets and on the other hand, small board size and less debt could also lead the firms towards the developed financial markets.

Furthermore, the researcher has also found out that there is positive relationship between corporate governance and the value of the firms both in developed and developing markets. Zelenyuk and Zheka [40] argued that corporate governance has become more important in the last decades in particular because the firms have reached a remarkable output growth and now they are earning more than $90 \%$ of the all world output. Nowadays, corporate governance is also being used for the security of the firms and for the continuous development of the firms in the world. Using the transition economies this work is aimed at establishing that there is positive, significant and causal relationship between corporate of provisions marketed by corporate governance affects the firm performance, these findings also have been corroborate by Lawrence D. Brown and Marcus L. Caylor, in 2006.

Holmstrom and Kaplan [21] insisted that the characteristic of corporate governance in U.S. firms is not constant over time, but has changed substantially in the last 20 years. Corporate governance in the 1980s was dominated by intense merger activity distinguished by the prevalence of leveraged buyouts (LBOs) and hostility, and promotes managers to improve the management efficiency. After a brief decline in the early 1990s, substantial merger activity resumed in the second half of the decade, while LBOs and hostility did not. Instead, the new corporate governance mechanisms, such as introducing stock option plan and EVA, appear to have played a larger role in the 1990s. In addition, institutional investors, such as pension funds, come to be large shareholders, and thus are likely to serve as monitors. The U.S. style of corporate governance has reinvented itself, and the rest of the world, including France, Germany, and Japan, seems to be following the same path.

Some of the recent research papers try to make comparative studies and determine relative merits of various kinds of corporate governance system as we have mentioned above. But the best corporate governance system that is applicable for all the nations does not exist. The best governance will change according to the legal system, economic structures, economic conditions, and so forth. We also have to pay an attention to the institutional complementarities of various systems in considering the appropriate corporate governance.

\section{Research Methodology}

The study employed a composite exploratory and survey design methodology drawing from previous studies in related areas. The top ten (10) manufacturing companies listed on the Nigerian Stock Exchange were selected because they were perceived to have the resources and motivation to enjoy the advantages of adopting suitable corporate governance practices. Furthermore, these companies were better performers, exhibited higher stock returns and were assumed to engage in good governance practices. The study examined the data for the years 2003 to 2010 . The reason for selection of the years was that the corporate governance guidelines were introduced in 2003. Seven years later, 2010, was considered appropriate time period, in which companies which had adopted the practices would have shown some changes in the implementation of the practices.

Data were collected from primary and secondary sources. Primary data were generated through structured questionnaire administered to 100 respondents in 10 manufacturing firms that are listed on the Nigerian Stock Exchange. The questionnaire was structured into two sections. The first section elicited information on demographic characteristics of the respondents. The second section elicited information relating to respondents' views on corporate governance practices in the manufacturing sector. Corporate governance practices of interest were firms' compliance with legal and regulatory guidelines (LECOM), board composition (BOCOM) and proactive stance (PROAC).

The target respondents comprised top-level and mediumlevel management members of the firms in the sample. However, eighty (80) out of the one hundred (100) copies of the questionnaire administered were returned and correctly filled. The number represented eighty percent (80\%) response rate. Consequently, data presentation and analysis were based on responses extracted from the eighty (80) copies of the questionnaire. The responses were codified and extracted into code manual to generate quantitative data for empirical analysis based on the average responses of the respondents. The data set so generated constituted the independent variables that were analyzed descriptively and entered into the panel regression model for empirical analysis.

Secondary data were extracted from published financial statements and annual reports of the selected firms. Performance variables of interest were profit after tax (PRATA), total equity shares in issues (TESII) and return on equity (ROE). Since return on equity was not directly observable, it was computed as the ratio of profit after tax to total equity shares in issue. This computation was the only modification to the published data collected for presentation and analysis. The ROE derived as ratio of PRATA to TESII was used as a proxy variable for firms' performance and treated as the dependent or response variable in the panel regression model. The data covered a period of eight years (2003 - 2010) and across the selected ten (10) firms. Therefore, the secondary data had both time series and crosssectional dimensions, which necessitated the need to stack the data into panel structure to process the data into eighty (80) observations and, thus, equate data points with the number of respondents.

To examine the effect of corporate governance practices on firms' financial performance and investigate the extent to which manufacturing companies have adopted Code of Best Practice on corporate governance outlined in 2003 and the changes to corporate governance practices years after up to 
2010, a composite panel data analysis was carried out with Econometric Views 7 (E-Views 7) statistical software facilitating the process. A hypothetical functional relationship was theorized to be existing between firms' performance variable (ROE) and corporate governance practices (LECOM, BOCOM and PROAC), and a multiple panel regression model of the relationship was specified as the foundation of the empirical analysis.

Using these sets of data and employing panel least squares (PLS) estimation techniques, the numerical values of the model intercept and coefficients (effects) were obtained and discussed vis-a-vis a priori expectations. Estimates were further evaluated for statistical significance as the basis for acceptance or rejection of the respective research hypotheses. Relevant statistics for test of significance were the t-statistic for isolated effects and the F- statistics for significance of joint effect of the corporate governance variables on firms' performance. Further evaluation was carried out to determine the extent to which corporate governance practices in the analysis explain variations in performance of the firms. Relevant statistics for the evaluation was the coefficient of multiple determinations (R-squared). These evaluations provided insight into how well changes in one firms' performance could be predicated on the practices of corporate governance.

A Priori Expectation of the study is that the more the firms' boards adhere to laid down legal and regulatory guidelines, given conducive manufacturing business climate, the better their performance was expected to be, and vice versa. Similarly, the more board membership was composed according to guidelines, the better the expected performance, or the other way round. Further, for a manufacturing-friendly business environment, firms' or sector's performance was expected to be enhanced with more proactive board. Performance was expected to decline the less proactive the board was. When none of the corporate governance practices included in the model was the experience in the firms, the sector was possibly expected to still achieve some positive level of performance. Consequently, positive but unsustainable performance level was expected in the absence of practice of corporate governance, and each of the corporate governance variables considered in this study was expected to have positive effect on performance of firms in the manufacturing sector. Symbolically, $\beta \mathrm{i}(\mathrm{i}=0,1,2,3)>0$.

\section{Results, Findings and Discussions}

The analysis was done in two stages. The first stage was descriptive which employs relevant statistical tools and statistics to describe certain attributes of the secondary and primary data. It discusses various central values of the secondary data. Values of specific interest include the sector mean, median, minimum and maximum performance measures. It also discusses the distribution of the respondents and their responses in terms of frequency and percentages. This enhances insight into respondents' views on practice of corporate governance in the manufacturing sector. The second stage is empirical analysis, which entails use of specified analytical stochastic model to investigate the relationship between corporate governance practice and performance, and the effect of the former on the later. The model abstracts theorizes the dependency relationship between corporate governance practice firm performances.

An aggregated multiple panel regression models used by Kajola [23] were adopted for the empirical analysis. The model enhances determination of effects of the corporate governance practices on financial performance. The performance variable considered in the study is return on equity (ROE) while corporate governance practices of interest are legal/regulatory compliance (LECOM), board composition (BOCOM) and board/management proactive strategies (PROAC). Since the data on corporate governance and performance variables exhibit time series $(t=2003$, $2004,2005 \ldots 2010$ time periods) and cross-sectional $(i=1,2$, 3, 10 firms) characteristics, they entered the model as panel data. This translates to the data amounting to 80 observations and equating the number of respondents. Consequently, the resulting panel regression model aptly reflects sector-based description and analysis.

Theoretically, the model states that the performance of the Nigerian manufacturing sector depends on the practice, not necessarily the structure, of corporate governance. Thus, the model considers legal compliance, rule-guided board composition and proactive reflexes of the board as indicators of corporate governance in practice. These indicators combine to determine performance as measured by return on equity, which is treated as the dependent variable in this study.

The Functional Relationship: Deriving from the above theoretical underpinning is the following functional relationship in the manufacturing sector as already stated in chapter three which is recapitulated below ROE « $\mathrm{f}$ (LECOM, BOCOM, PROAC)

Where:

ROE is the sector's return on equity.

LECOM is the extent of legal compliance by boards in the sector.

BOCOM denotes adherence to stipulated rule in board composition.

PRO AC is a measure of how proactive the boards are in their strategies.

The Panel Regression Model- The sector functional link above translates to the stochastic panel model specified below. The stochastic nature of the model is justified on the ground that this analysis recognizes the possibility of other variables not considered, included in the exerting influence on performance of firms in the manufacturing sector. ROE, which is treated as dependent variable in this analysis is derived as the ratio of PRATA to TESII for the respective firms. PRATA and TESII are extracted as published in the financial statements of the selected quoted manufacturing firms. Firms' performance variables (LECOM, BOCOM and PROAC), which entered the model as independent variables, are respondents' views expressed through responses and 
quantified via a four-scale code and code manual. The resulting data sets are stacked into panel structure because of their longitudinal and cross-sectional characteristics.

Estimation of the panel model enhanced determination of the respective effects of corporate governance practice variables on performance of manufacturing firms. The statistical software, Econometric Views version7 (EViews7) enhanced derivation of ROE, estimation of effects (in their numeric form) of the corporate governance practices on performance, and computation of relevant statistics for further analysis and evaluation. Consequently, the model is specified as:

$$
\mathrm{ROE}=\beta_{0}+\beta \mathrm{iLECOM}+\beta_{2} \mathrm{BOCOM}+\beta_{3} \mathrm{PROAC}+\mu
$$

Where $\beta_{0}$ is Intercept: It denotes level sector performance (using ROE as a proxy) that is independent on the corporate governance practice variables in the model.

$\beta i \quad(i=1,2,3)$ are the effects (coefficients) of the respective corporate governance practices. The intercept and coefficients constitute model parameters.

( $x$ is the stochastic variable to accommodate influences of other variables that might affect performance but which are not included in the model.

ROE, LECOM, BOCOM and PROAC are as defined earlier. A Priori Expectation- The more the firms' boards adhere to laid down legal and regulatory guidelines, given conducive manufacturing business climate, the better their performance is expected to be, and vice versa. Similarly, the more board membership is composed according to guidelines, the better the expected performance, or the other way round. Further, for a manufacturing-friendly business environment, firms' performance is expected to be enhanced with more proactive board. Performance is expected to decline the less proactive the board is. When none of the corporate governance practices included in the model is the experience in the firms, the sector is possibly expected to still achieve some positive level of performance. Consequently, positive but unsustainable performance level is expected in the absence of practice of corporate governance, and each of the corporate governance variables considered in this study is expected to have positive effect on performance of firms in the manufacturing sector. Symbolically, $\beta \mathrm{i}(\mathrm{i}=0,1,2,3)>0$.

Estimation of the Intercept and Model Coefficient: Numerical values of model parameters are obtained through the process of regression analysis. The process yields numerical values of the intercept (attainable aggregated performance level of firms in the sector that is independent of corporate governance practices) and coefficients (effects) of the respective corporate governance practices on performance of performance of firms in the manufacturing sector. Estimation of the values was facilitated with the EViews7 statistical software, via the Panel Least Squares (PLS) techniques. Stacking the data in panel structure translated to 80 sample observations for the $2003-2010$ study period with $\mathrm{t}=8$ years and $\mathrm{i}=10$ firms. Results of the regression analysis are presented below.

Table 1. Relationship between Corporate Governance and Firm Performance.

\begin{tabular}{lllll}
\hline Variable & Coefficient (Pi) & Std. Error & t-Statistic & Prob. \\
\hline Intercept & 1.423654 & 1.467230 & 0.970301 & 0.3351 \\
LECOM & 0.197462 & 0.394874 & 0.500063 & 0.6186 \\
BOCOM & -0.443075 & 0.555055 & -0.798255 & 0.4273 \\
PROAC & -0.234502 & 0.364761 & -0.642892 & 0.5223 \\
R-squared 0.283209 Adjusted R-squared 0.213521 Sum & F-statistic 4.063955 Prob (F-statistic) 0.000832 Durbin-Watson \\
Squared Residual 13.80822 & & Statistic 1.170755 & \\
\hline
\end{tabular}

Estimated Model: To express the estimated panel regression model, numerical values of the intercept and coefficients of corporate governance practices are substituted into the specified model, with a designating estimate of the stochastic variable. Each coefficient captures the nature and magnitude of the effect of unit change in the respective corporate governance practices on firms' performance.

$$
\begin{gathered}
\mathrm{ROE}=1.4237+0.1975 \mathrm{LECOM}-0.4431 \mathrm{BOCOM}- \\
0.2345 \mathrm{PROAC}
\end{gathered}
$$

T stat $=0.97+0.50-0.80-0.64$

F stat $=4.06$

$\mathrm{DW}=1.17$

Evaluation of Estimated Model Parameters: The estimated parameters of the model are evaluated in two stages. In the first stage, the signs or directions of effects of changes in the respective corporate governance practices on performance are discussed vis-a-vis a priori expectations. The second stage is determination of significance or otherwise of effects of corporate governance practices on performance, extent to which the corporate governance practices explains variations in performance. This second stage of evaluation enhances decision to accept or reject the research hypothesis. Significance of isolated and joint effects of corporate governance practices on performance is evaluated using the $\mathrm{t}$ statistic and F-statistics respectively. Significance is considered at the 5\% level. Extent to which the practices explain performance dynamics is determined using the coefficient of multiple determinations (r-squared).

Parameter Estimates and Pre-Estimation Expectations: Estimated value of the intercept ( $\beta$ o - 1.423654) conforms to the expectation that some positive level performance would be attainable even when the firms do not comply with legal/regulatory guidelines, deviate from prescribed board composition and employ reactive rather than proactive approaches in their manufacturing activities. However, while the isolated effect of legal/regulatory compliance $(\beta \mathrm{i}=$ 0.197462 ) is consistent with expectation, isolated effects of board composition $(\beta o=-0.443075)$ and proactive stance $(\beta 3=-0.234502)$ as corporate governance practices in the 
sector are contrary to expectations, therefore, while legal compliance exerts positive effect on performance, the other aspects of corporate governance practices exert negative effects on performance. These suggest that, perhaps, while the boards of the firms comply with routine legal and regulatory guidelines, they do not adhere to similar provisions for board membership composition, and those boards and managements of the manufacturing firms are not really proactive to probable challenges in the manufacturing business environment. Alternatively, the composition of the boards adhered to guidelines and are proactive but at greater costs to their firms. Thus, the net effect on return on equity as a proxy for performance is negative.

Further, the results show that disregard to guidelines for composition of firms' boards or adherence to guidelines at rising costs has greater negative effect than the cost-driven proactive practice of the boards and managements $(\mathrm{Pi}=$ $0.443075>-0.234502)$. Similarly, the positive effect of legal compliance (0.197462) is of smaller magnitude than the respective effects of board composition and proactive practices (-0.443075 and -0.234502). A drawback of the result is that given the values of $t^{*}$, none of the variable is statistically significant. This is further explained below.

Decision Rule: If the probability associated with t-statistic of the coefficient or effect of given corporate governance practice on firms' performance variable is less than the specified significance level of $5 \%$, it is significant. That is, prob (t-statistic) $<0.05$. Otherwise, it is not significant. That is, Prob (t-statistic) $>0.05$.

Table 2. Coefficients or Isolated Effects, $t$-Statistic and Prob (t-statistic).

\begin{tabular}{|c|c|c|c|c|}
\hline Effect & t-statistic & Probability & Significance Level & $>$ or $<0.05$ Sig. Level \\
\hline $\mathrm{Pi}$ & 0.500063 & 0.6186 & 0.05 & $>$ \\
\hline P2 & -0.798255 & 0.4273 & 0.05 & $>$ \\
\hline & -0.642892 & 0.5223 & 0.05 & $>$ \\
\hline
\end{tabular}

Decision: From the relevant statistics of the regression results as shown in Table 2 above, each of the probabilities $(0.6186,0.4273$ and 0.5223$)$ associated with the respective coefficients or effects of the corporate governance practices on performance of the manufacturing sector is greater than the specified $5 \%$ level of significance. These provide empirical supports that at the 5\% level of significance, the corporate governance practices considered in this analysis exert insignificant effects on manufacturing firms' performance in isolation. That legal and regulatory consideration exerts positive but insignificant effect on performance, and board composition and proactive practice practices respectively exert negative though insignificant effects on performance. Consequently, the hypotheses $\mathrm{H} 01$, $\mathrm{H} 02$ and $\mathrm{H} 03$ respectively are accepted for the isolated effects of corporate governance practices used in the analysis. With this decision, research questions 1 to 3 are answered and specific objectives 1 to 3 achieved. This evaluation enables the determination of whether or not the aggregate effect of the corporate governance practices on firms' performance is significant. As in isolated effects, the joint effect is examined at the $5 \%$ level of significance.

Decision Rule: If the probability associated with computed Fstatistic is less than the specified significance level of $5 \%$, the joint effect is significant. That is, prob (F-statistic) $<0.05$. Otherwise, it is not significant. That is, Prob (F-statistic) $>0.05$.

Decision: From results of the regression analysis, the computed F-statistic of 4.063955 has associated probability of 0.000832 . With the probability that is less than the specified $5 \%$ level of significance, there is ample evidence that the aggregate effect of these corporate governance practices in the analysis on performance of the manufacturing sector is statistically significant. However, since the combined negative effect of board composition and proactive practices outweighs the positive effect of legal compliance, a significant negative relationship exists between the totality of corporate governance practices and firms' performance. Therefore, research hypothesis $\mathrm{H} 04$ is rejected with respect to the aggregate effect of corporate governance on firms' performance in the manufacturing sector. With this decision, research question 4 is answered and the major research objective is achieved.

Multiple regression analysis depicts the explanatory power of the corporate governance practices in firms' performance variations. The need to determine the extent to which the corporate governance practices included in the model explain variations in firms' performance necessitates this evaluation. Coefficient of determination (R-squared) is the relevant statistic to determine the power of the practices in explaining changes in performance of the firms. The computed coefficient of multiple determinations (R-squared) in the results of the panel regression analysis is 0.283209 or about $28.32 \%$. This coefficient of multiple determinations is low and, thus, provides empirical evidence that these corporate governance practices exhibit low power in explaining variations in performance of the firms in real life business activities of the manufacturing sector.

This supports hypothesis' H05, answers research question 5 and achieves the fifth objective of this research that is to determine the extent to which corporate governance practices and explain variations in the performance of the manufacturing firm. Therefore, the low explanatory power shows that some other aspects of corporate governance practices not considered in this study and, perhaps corporate governance structure, exhibit significant power and thus account for more of the variations (about $71.68 \%$ ) in firms' performance in the manufacturing sector. It also substantiates the possibility of high cost of corporate governance practices in the manufacturing sector

\subsection{Discussions}

Of particular interest is the finding that the individual and 
aggregated negative effects of board composition and proactive practices outweigh the positive effect of legal/regulatory compliance, though none was found to be significant. However, the joint effect of theses corporate governance practices on performance was found to be significant at the 5\% significance level. This implies that at the level of aggregation, the combined negative effects of board composition and proactive practices do not only outweigh the positive effect of legal compliance but also became significant. This provides further evidence that practice of corporate governance by the firms was possibly rising-cost driven and, hence, the significant combined negative effect of some aspects of the practices on performance.

Furthermore, it was found out that the corporate governance practices considered in the analysis exhibited low power in explaining variations in performance of the firms. This was evidenced by the coefficient of multiple determinations adjusted $R^{2}$, which showed about $28 \%$ explanatory power. The extent to which these corporate governance practices explain dynamism in performance was further lower at about $21 \%$ after adjusting for degrees of freedom in the model. This suggested that innovations in corporate governance practices in the manufacturing sector in Nigeria were still at a shallow stage. The low values of $\mathrm{T}$ statistics, F statistics and adjusted $R^{2}$ seem to affect the credibility of the result.

\subsection{Conclusion}

Since the joint effect of the aspects of corporate governance practices considered in this study on performance is significant, the study concludes that although these aspects of corporate governance practices exhibited low power in explaining variations firms' performance in the manufacturing sector, they are relevant determinants of the manufacturing sector firms' performance. Therefore, the study submits that corporate governance practices have significant effect on performance of the manufacturing firms. Low explanatory power of the corporate governance practices included in the analytical model is an indication that dynamism of operation performance in the manufacturing sector situates more in some other aspects of corporate governance than just the practices. The other aspects may likely be embedded in corporate governance structure. Moreover, this provides evidence that corporate governance innovations in the manufacture are yet to be deep-rooted. Also, the weak monitoring and enforcement mechanisms act as a serious deterrent to business growth, since errant firms know that the chances of getting penalized are minimal or non-existent

The positive effect of compliance with legal and regulatory guidelines indicated the greater compliance would induce greater positive effect and ultimately result to significant increases in return on equity. Cost-saving board composition and proactive practices would mitigate the negative effects on performance and, thus, enhance return on equity. Board composition that negates legal and regulatory guidelines or adherence to guidelines at rising management costs has more damping effect on performance than cost-driven proactive practice of the firms' boards and managements. Combined negative effect of cost-inducing board composition and proactive practices crowds out the positive effect of legal/regulatory compliance.

\subsection{Recommendations}

Anchored on the above summary of findings and conclusion, the following recommendations are made:

Firms in the manufacturing sector should:

(1) Ensure greater compliance with legal and regulatory requirements since it was found to be performance enhancing. This would ultimately translate to significant positive effect on performance via substantial increases in return on equity.

(2) Embark on cost-saving composition of board size and structure as well as proactive strategies in order to reverse the negative effects on operational performance.

(3) Ensure optimal compliance with laid down rules, optimal board composition proactive practices to push for significant positive effect on performance of corporate governance practices in the sector.

(4) Evolve additional corporate governance practices to mitigate the overbearing negative effects of board composition and proactive practices of the boards and managements. This will likely reverse the negative effects and enhance the power of corporate governance practices in explaining dynamics of operational performance.

(5) Where appropriate, substitute newfound more performance-friendly corporate governance practices for those considered in this analysis whose effects on performance were negative.

(6) They should look beyond corporate governance structure and incorporate these and other corporate governance practices into their management policies within their internal and external business environments.

(7) Embark on holistic re-examination of corporate governance practices in the sector to enhance their update and dialogue with legal/regulatory authorities in the manufacturing sector.

Government and Regulatory agency in the manufacturing sector should:

a) The regulatory agency for companies should develop a checklist with which firms can score them on the aspect of compliance with corporate governance practice. This score should become an inherent component of every firm's (public and private) annual financial report.

b) To ensure adherence to the rules of scoring, there should routine and sentinel auditing of the scoring by the regulatory agency concerned. It is important to ensure deeper investor engagement and involvement in the affairs of the companies. To facilitate this, firms 
should set fairly high or competitive standards in the selection of non-executive and independent directors for board committee duties. This is critical if such committees are to have strong impact on governance of the firm

c) As the regulatory approach in Nigeria is predominantly mandatory rather than voluntary, a move towards a more voluntary approach to regulation may be more effective bearing in mind the absence of a legal and enforcement framework as well as the fast pace with which business policies change.

d) The performance of firms in Nigeria may develop faster under a more fluid system, which allows the incorporation of new ideas, and processes to enable businesses compete favorably with international firms.

\section{References}

[1] Aduda, J., Chogii, R. \& Magutu, P. O. (2013). An Empirical Test of Competing Corporate Governance Theories on the Performance of Firms Listed at the Nairobi Securities Exchange. European Scientific Journal; May 2013 Edition, Vol. 9, No. 13.

[2] Akinsulire, O. (2006). Financial Management, 4th Edition. Lagos: El-Toda Ventures.

[3] Al-Matari, Y. A., Al-Swidi, A. K. \& Bt-Fadzil, F. H. (2012). Corporate Governance and Performance of Saudi Arabia Listed Companies. British Journal of Arts and Social Sciences; Vol. 9, No. I.

[4] Babalola, A. \& Adedipe, O. A. (2014). Corporate Governance and Sustainable Banking Sector: Evidence from Nigeria. Research Journal of Finance and Accounting; Vol. 5, No. 12.

[5] Babalola, A. (2014). Corporate Governance and Cooperative Societies: A Survey of Tertiary Institutions in Oyo, Nigeria. Developing Country Studies; Vol. 4, No. 12.

[6] Bhimani, A. (2008). Making Corporate Governance Count: The Fusion of Ethics and Economic Rationality. Journal of Management and Governance; 12 (2), 135-147.

[7] Brava, A., Jiangb, W., Partnoye, F. \& Thomasd, R. (2006). Hedge Fund Activism Corporate Governance and Firm performance. Journal of Finance; Vol. 59, No. 4, pp. 17291775 .

[8] Cheema-Rehman, K. U. \& Din, M. S. (2013.) Impact of Corporate Governance on Performance of Firms: A Case Study of Cement Industry in Pakistan. Journal of Business and Management Sciences; Vol. 1, No. 4, 44-46.

[9] Claessens, S. \& Fan, J. P. H. (2002). Corporate Governance in Asia: A Survey. International Review of Finance; Vol. 3, No. 2, pp. 71-103.

[10] Clark, T. (2004). Theories of Corporate Governance: The Philosophical Foundations of Corporate Governance. New York: Routledge Publishing.

[11] Cooray, A. \& Wickremasinghe, G. B. (2007). The Efficiency of Emerging Stock Markets: Empirical Evidence from the South Asian Region. Journal of Developing Areas; Vol. 41, No. 1, pp. 171-183.
[12] Crane, A. \& Matten, D. (2007). Business Ethics, 2nd Ed. London, Oxford University Press.

[13] Cremers, K. J. \& Nair, V. B. (2005) Governance Mechanisms and Equity Prices. The Journal of Finance; 60. 6: 2859-2894.

[14] Daily, C. M., Dalton, D. R. \& Canella, A. A. (2003). Corporate Governance: Decades of Dialogue and Data. Academy of Management Review; 28 (3), 371-382.

[15] Donaldson, T. \& Preston, L. E. (1995). The Stakeholder Theory of the Corporation: Concepts, Evidence and Implications. Academy of Management Review; 20 (1), 65-91.

[16] Duchin, R. \& Sosyura, D. (2011). The Politics of Government Investment. Ross School of Business, University of Michigan. Retrieved from http://webuser.bus.umich.edu/dsosyura/Research\%20Papers/P olitics\%20of\%20Government\%20Investment.pdf

[17] Ghabayen, M. A. (2012). Board Characteristics and Firm Performance: Case of Saudi Arabia. International Journal of Accounting and Financial Reporting; Vol. 2, No. 2.

[18] Haniffa, R. \& Hudaib, M. (2006). Corporate Governance Structure and Performance of Malaysian Listed Companies. Journal of Business Finance and Accounting; Vol. 33, No. 7 \& 8, pp. 1034-1062.

[19] Heenetigala, K. (2011). Corporate Governance Practices and Firm Performance of Listed Companies in Sri Lanka. Doctor of Business Administration Dissertation, submitted to Victoria Graduate School, Faculty of Business and Law, Victoria University, Melbourne (April).

[20] Hillman, A., Cannella, A. \& Paetzold, R. (2000). The Resource Dependence Role of Corporate Directors: Strategic Adaptation of Board Composition in Response to Environmental Change. Journal of Management Studies; 37 (2): 235-256.

[21] Holmstrom, B. \& Kaplan, S. N. (2001). Corporate Governance and Merger Activity in the United States: Making Sense of the 1980s and 1990s. Journal of Economic Perspectives; Volume 15, Number 2-Spring 2001-Pages 121-144.

[22] Ironkwe, U. \& Adee, G. M. (2014). Corporate Governance and Financial Firms Performance in Nigeria. Journal of Exclusive Management Science - August 2014 -Vol 3, Issue 8.

[23] Kajola, S. O. (2008). Corporate Governance and Firm Performance: The Case of Nigerian Listed Firms. European Journal of Economics, Finance and Administrative Sciences, Issue 14.

[24] Magdi, R. \& Nadareh, R. (2002). Corporate governance: A framework for implementation. Britain World Group Journal; Vol. 20, pp 123-132.

[25] Maher, M, \& Anderson, T. (2008). Corporate Governance: Effects on Firm Performance and Economic Growth. Contemporary Accounting Research; Vol. 25, pp 351-405.

[26] Masih, A. M. M. (2005). Macroeconomic Policy Trilemma in Open Economies: Which Policy Option is Ideally Suited to the Malaysian Context? Jurnal Pengurusan; 24 (2005) 3-26.

[27] Mathiesen, H. (2002). Managerial Ownership and Financial Performance. Ph.D. Dissertation, Series 18.2002, Copenhagen Business School, Denmark, viewed. 
[28] Mobius, J. M. (2002). Issues in Global Corporate Governance, in Lc Keon (ed.), Corporate Governance: An Asia-Pacific Critique, Sweet \& Maxwell Asia, Hongkong.

[29] Monks, R. A. G. \& Minow, N. (2004). Corporate Governance. MA: Blackwell Publishing.

[30] Mulili, B. M. \& Wong, P. (2011). Corporate Governance Practices in Developing Countries: The Case for Kenya. International Journal of Business Administration; Vol. 2, No. 1; February.

[31] Muogbo, U. S. (2013). Impact of Privatization on Corporate Performance: A Study of Selected industries in Nigeria. International Journal of Humanities and Social Science Invention; Volume 2 Issue 7 || July. 2013|| PP. 81-89.

[32] Nworji, I. D., Olagunju, A. \& Adeyanju, D. O. (2011). Corporate Governance and Bank Failure in Nigeria: Issues, Challenges and Opportunities. Research Journal of Finance and Accounting; Vol. 2, No 2.

[33] Olusanya, O. O. \& Oluwasanya, A. T. (2014). Effect of Corporate Governance on the Survival and Sustainability of Banks in Nigeria. American Journal of Engineering Research (AJER); Volume-03, Issue-02, pp-73-83.
[34] Organization for Economic Co-Operation and Development (2004). OECD Principles of Corporate Governance. Paris Cedex 16, France: OECD Publications Service.

[35] Padilla, A. (2002). Can Agency Theory Justify the Regulation of Insider Trading? The Quarterly Journal of Austrian Economics; Vol. 5, No. 1, pp. 3-38.

[36] Rezaee, Z. (2009). Corporate Governance and Ethics. NY, USA: John Wiley \& Sons, Inc.

[37] Sundaram, A. K. \& Inkpen, A. C. (2004). The Corporate Objective Revisited. Organization Science; 15 (3), 350-363.

[38] Wanyama, D. W. \& Olweny, T. (2013). Effects of Corporate Governance on Financial Performance of Listed Insurance Firms in Kenya. Public Policy and Administration Research; Vol. 3, No. 4.

[39] Wheeler, D., Colbert, B. \& Freeman, R. E. (2003). Focusing On Value: Reconciling Corporate Social Responsibility, Sustainability and a Stakeholder Approach in a Network World. Journal of General Management, Vol. 3, No. 4, 2013, 28, 1-28.

[40] Zelenyuk, V. \& Zheka, V. (2006). Corporate Governance and Firms' Efficiency: the Case of Transitional Country, Ukraine. Journal of Productivity Analysis; V. 25, Numbers 1/2, 143-169. 